\title{
Interactions with mycorrhizal fungi in two closely related hybridizing orchid species
}

\author{
Alessia luca, Francesca Bellusci, Giuseppe Pellegrino* \\ Department of Biology Ecology and Earth Science, University of Calabria, \\ Via Bucci 6/B, I-87036 Rende (CS), Italy
}

\begin{abstract}
The nuclear ribosomal DNA was used to identify the orchid mycorrhizal fungi found in roots of Orchis xbivonae and its parental species Orchis anthropophora and Orchis italica. Polymerase chain reaction products were sequenced and identified using the expanded database. We determined that closely related Tulasnellaceae are mycorrhizal in the three orchid taxa, suggesting that the mycorrhizal partner does not impair hybrid survival. This study demonstrates that $O$. xbivonae displays few differences in comparison with its two parental species in identity of its associated mycorrhizal fungi, it is a short-term by-product of the hybridizing behavior of common pollinators, and thus it will not easily origin descendents with potential new genetic combinations and/or ecological preferences.
\end{abstract}

Keywords: Mycorrhizal fungi, nrDNA, Orchis anthropophora, Orchis italica, Orchis xbivonae, Tulasnellaceae

\section{Introduction}

The Orchidaceae is one of the largest plant families with close to 25,000 species and a circum-global distribution (DRESSLER 1993, CRIBB et al. 2003). It is also one of the most complex plant families with many adaptations. One adaptive mechanism is related to reproductive biology, indeed orchid flowers evolved a close relationship with insect pollinators such that sympatric species can be pollinated by different insect species (VAN DER PIJL and Dodson 1966), maintaining species isolation (SCOPECE et al. 2007). Interestingly, $30 \%$ of orchid species shows non-rewarding flowers (RENNER 2005), attracting pollinators by generalized food deception, mimicry or sexual deception (JERSAKOvA et al. 2006). Another example of adaptive mechanism is related to mycorrhizal interactions that have allowed orchids to fit in several habitat types and has led to colonize worldwide. The main group of fungi inhabiting orchid roots is Basidiomycetes (RASMUSSEN 2002), though Ascomycetes have been found (SELOSSE et al. 2004). Mycorrhizal fungi provide the basic

* Corresponding author, e-mail: giuseppe.pellegrino@unical.it

Copyright $^{\circledR} 2014$ by Acta Botanica Croatica, the Faculty of Science, University of Zagreb. All rights reserved. 
organic carbon (SMITH 1966, CAMERON et al. 2006) and carbohydrates for seedling growth (LEAKE 1994, RASMUSSEN 1995). Also adult individuals of achlorophyllous and photosynthetic orchids obtain part of carbon heterotrophically by mycorrhizal fungi (BIDARTONDO et al. 2004, Julou et al. 2005, SElOSSE and Roy 2009, JACQUEMYN et al. 2010). In addition, in an adult green-leaved orchid Goodyera repens, there is a flow of carbon from the plant to the fungus (CAMERON et al. 2006). This suggests that also the green-leaved adult orchids, after the initially mycoheterotrophic phase of development, establish the general symbiotic relationship with fungi in which carbon from the plant is exchanged for mineral nutrients gathered by the fungus.

In recent years, the application of modern molecular approaches has increased greatly the facility for identifying the mycobionts. From the beginning of 2000, a large number of orchid mycorrhizal has been identified directly from orchid roots, tubers and rhizomes through molecular biology techniques (SHEFFERSON et al. 2007, STOCKINGER et al. 2010, JACQUEMYN et al. 2011a). The main widespread molecular markers used to identify orchid mycobionts are the internal transcribed spacers (ITSs) of the nuclear ribosomal DNA using primer sets (WHITE et al. 1990, TAYLOR and MCCORMICK 2008) for PCR amplification.

The level of specificity between fungus and orchid is an important factor determining chances of successful seedling establishment (BIDARTONDO and READ 2008). Early molecular studies have revealed that terrestrial orchids interact with a wide range of mycorrhizal fungi. Some orchids are extreme specialists and are associated to a single fungal species (McCormick et al. 2004, TAYlor et al. 2004, DeArlaney 2007, SHEFFERSON et al. 2008), while others are generalists, hosting many different fungi (MCCORMICK et al. 2006, BONNARDEAUX et al. 2007, IRWIN et al. 2007, Roy et al. 2009).

The requirement of terrestrial orchids to form a symbiosis with mycorrhizal fungi may act on orchid distribution and diversification (WATERMAN et al. 2008, PHILLIPS et al 2011). A large diversity and distribution of orchids is related to a broadly distributed fungi (OTERO et al. 2007), while rarity of orchids and narrow distribution is associated to a narrow mycorrhizal specificity (VALADARES et al. 2012).

Hybrid zones, in which hybrids live sympatrically with parental species, are highly suitable to verify mycorrhizal hybrid preferences, that means do hybrids form a symbiosis with the same fungi of one or both parents? or have totally different partners? There are only few studies that have investigated mycorrhizal associations in hybrid compare to parental species. Previous studies showed that hybrids of genus Caladenia had fungi genetically different from those associating with parental species (HoLLICK et al. 2005), while adult individuals of Orchis simia and O. anthropophora and their hybrid were associate to closely related Tulasnellaceae fungi (SCHATZ et al. 2010), such as three closely related hybridizing Orchis species showed common mycorrhizal associations in protocorms and adult stage (JACQUEMYN et al. 2011b).

In this study, we examined, with molecular analyses, a sympatric zone between Orchis italica Poir. and $O$. anthropophora L., which hybridize to form O. xbivonae Tod. Our main aim was to compare the identity of mycorrhizal associates in two parental species $O$. italica, O. anthropophora, and their hybrid O. xbivonae at the adult stage to determine if lack of appropriate fungal symbionts can be related to hybrid viability, and to study the role of mycorrhizal associations in allowing to the hybrid to exploit prospective new ecological niches different from parental habitat. 


\section{Materials and methods}

\section{Study area and orchid species}

The study on Orchis italica Poir., O. anthropophora (L.) All., and their hybrid Orchis xbivonae Tod. was conducted in a natural population located onto the »Monte di Cassano $\left(39^{\circ} 47^{\prime} \mathrm{N}, 16^{\circ} 18^{\prime} \mathrm{E}, 512 \mathrm{~m}\right.$ a.s.1.), one kilometre north-west of the city of »Cassano allo Ionio« (northern Calabria region, Italy). The whole area covers roughly $1,500 \mathrm{~m}^{2}$ (25 m wide and $60 \mathrm{~m}$ long) of calcareous soil and is bounded on the west by a road and on the remainder by deep gorges.

In the studied site, Orchis italica and O. anthropophora overlap extensively in their spatial distribution and flowering time (flowering peak between the end of April and the middle of May) and grew together with O. xbivonae (PELLEGRINO et al. 2009).

Orchis italica and $O$. anthropophora are closely related (BATEMAN et al. 2003), have same chromosome number $(2 n=42)$ (QueIros 1985, CAUWET-MARC and BALAYER 1986, BiAnco et al. 1987, Costantinidis et al. 1997) and have been both included in the $O$. militaris (DELFORGE 2005) or »anthropomorphic « group (BATEMAN et al. 2003). Orchis italica show a pendent lip, deeply tri-lobed and with a cylindrical spur, while, O. anthropophora has a narrow lip and, differently from all the others Orchis species, it lacks a spur (DELFORGE 2005). The detected specimens of $O$. xbivonae are $20-40 \mathrm{~cm}$ high, with oblong leaves and cylindrical inflorescences. The pendent labellum is trilobate with median lobule reduced to a minuscule dent. Spur is very short, saccate and pointing downwards, with a length of about the half of that of $O$. italica.

\section{Molecular analysis}

Molecular characterization of mycorrhizae involved: (i) extraction of DNA from orchid roots, (ii) amplification of nuclear ribosomal DNA regions useful in determining fungal identity, (iii) DNA sequencing for identification of mycorrhizal fungi and assessment of specificity levels.

Small parts of roots were cut from 15 randomly selected individuals of Orchis anthropophora and $O$. italica and for 8 individuals of $O$. xbivonae (all hybrids found) for molecular analysis. All roots were surface sterilized using $1 \%$ hypochlorite $(30 \mathrm{~s})$ followed by three rinses in distilled water ( $30 \mathrm{~s}$ ). Total DNA was extracted from 1-2 cm length of root pieces per plant using the cetyltrimethyl ammonium bromide (CTAB) method (DOYLE 1991). DNA was resuspended in $50 \mu \mathrm{L}$ of distilled water.

To discriminate among fungal taxa colonizing orchid roots, the internal transcribed spacers (ITSs) of the nuclear ribosomal DNA were amplified using fungal universal primer pairs ITS1-OF and ITS4-OF (TAYLOR and MCCORMICK 2008) chosen for their most constant and reliable amplification (JACQUEMYN et al. 2011b).

PCRs were performed on a PTC-100 Thermal Cycler (MJ Research Inc., Watertown, MA, USA) according to the following thermal cycling profile: $94{ }^{\circ} \mathrm{C}$ for $3 \mathrm{~min}$ (1 cycle), $94{ }^{\circ} \mathrm{C}$ for $45 \mathrm{~s}, 58^{\circ} \mathrm{C}$ for $45 \mathrm{~s}, 72^{\circ} \mathrm{C}$ for 1 min $(30$ cycles $) ; 72^{\circ} \mathrm{C}$ for $5 \mathrm{~min}$ (1 cycle). Amplification products were electrophoretically separated on a $1.8 \%$ agarose gel (Methaphore, FMS), photographed after ethidium bromide staining and purified with the QIAEX II Gel Extraction Kit (QIAGEN) to remove unincorporated primers and dNTPs following the 
manufacturer's instructions. The purified PCR fragments were sequenced directly in forward and reverse directions; fluorescent dye sequencing was performed on a 310 Prism ABI DNA Genetic Analyzer (Applied Biosystems, Carlsbad, California, USA).

\section{Data analysis}

The ClustalW algorithm (THOMPson et al. 1994) of the Molecular Evolutionary Genetics Analysis version 5 (MEGA5) program package was applied for the exact alignment of sequences (TAMURA et al. 2011). Ambiguous sites were checked manually and corrected by comparing electropherograms from both strands. Consensus sequences were obtained for each specimen (5' and 3 ' borders were identified using mycorrhizal sequences already available in DNA DATA BANK OF JAPAN (2013).

Sequence identity was determined using the blast algorithm available through the NATIONAL CENTER FOR BiOTECHNOLOGY INFORMATION (2013). In addition, since none of the ITS sequence types obtained had $100 \%$ identity with GenBank sequences of identified Rhizoctonia group, OTUs were identified comparing our ITS sequences and previously developed mycobionts OTUs. The identification of OTUs was performed comparing the sequences obtained in this study with those of JACQUEMYN et al. (2011b) using the ClustalW algorithm of the MEGA 5 program package. Our fungi sequences were classified as OTUs when ITS sequence similarity exceeded $97 \%$. Pairwise genetic distances between sequences were measured by the number of nucleotide substitutions occurring between them under the Tamura and Nei model (TAMURA and NeI 1993). A neighbour-joining tree (SAITOU and NEI 1987) was constructed using Clustal and displayed by TreeView v.1.6.6. Differences in mycorrhizal assemblages between taxa were analysed using a one-way ANOVA. When the F test was significant, means were compared using the Tukey test at $5 \%$ error probability.

\section{Results}

The identification of orchids associated fungi by molecular techniques was successful for all the collected samples. On the basis of less than $5 \%$ of genetic distance (Tab. 1), out of 23 fungal OTUs identified previously (JACQUEMYN et al. 2011b) eight were observed (OTU $2,4,6,7,10,11,12$ and 17) in our investigated plants; six were related to Tulasnellaceae, and two to Ceratobasidiaceae (Tab. 2). Six different fungal OTUs were found in Orchis italica (OTU 2, 4, 7, 10, 12 and 17) and O. anthropophora (OTU 2, 4, 6, 7, 10 and 11), and four (OTU 2, 4, 7 and 10) in O. xbivonae (Fig. 1). Parental species showed different frequently dominant OTUs (OTU 2 and 12 in O. italica and OTU 7 and 10 in O. anthropophora). OTU 2 and 4 were found in all three taxa, while $O$. italica and $O$. anthropophora showed two exclusive OTUs, OTU 12 and 17, OTU 6 and 11, respectively (Fig. 1). Phylogenetic analysis placed ITS sequences for Orchis italica, $O$. anthropophora and $O$. xbivonae in eight distinct groups closely associated with OTUs (Fig. 2).

ANOVA analysis showed no significant differences in mycorrhizal assemblage between parental species and hybrids, (O. anthropophora vs $O$. xbivonae: $\mathrm{F}_{1,21}=1.004, \mathrm{p}=0.35, O$. italica vs $O$. xbivonae: $\mathrm{F}_{1,21}=0.785, \mathrm{p}=0.38$ ), although the parental species have a slight different assemblages $\left(O\right.$. anthropophora vs O. italica: $\left.\mathrm{F}_{1,28}=3.411, \mathrm{p}<0.05\right)$. 
Tab. 1. Genetic distance between fungal operational taxonomic units (OTUs) identified in Orchis italica (I), O. anthropophora (A) and O. xbivonae (B). Less than 5\% of genetic distance is marked in bold.

\begin{tabular}{|c|c|c|c|c|c|c|c|c|}
\hline Orchis species & OTU2 & OTU4 & OTU6 & OTU7 & OTU10 & OTU12 & OTU17 & OTU11 \\
\hline I 33 & 0.004 & 0.327 & 0.317 & 0.321 & 0.334 & 0.121 & 0.420 & 0.438 \\
\hline I 20 & 0.005 & 0.324 & 0.319 & 0.323 & 0.334 & 0.122 & 0.413 & 0.434 \\
\hline I 28 & 0.004 & 0.324 & 0.313 & 0.315 & 0.331 & 0.118 & 0.420 & 0.434 \\
\hline I 22 & 0.005 & 0.325 & 0.314 & 0.316 & 0.332 & 0.118 & 0.420 & 0.435 \\
\hline I 30 & 0.327 & 0.004 & 0.133 & 0.097 & 0.200 & 0.329 & 0.339 & 0.354 \\
\hline I 24 & 0.324 & 0.007 & 0.135 & 0.101 & 0.200 & 0.327 & 0.343 & 0.357 \\
\hline I 29 & 0.320 & 0.107 & 0.113 & 0.009 & 0.228 & 0.351 & 0.380 & 0.376 \\
\hline I 25 & 0.318 & 0.103 & 0.105 & 0.005 & 0.223 & 0.345 & 0.377 & 0.373 \\
\hline I 27 & 0.342 & 0.204 & 0.231 & 0.226 & 0.015 & 0.349 & 0.412 & 0.407 \\
\hline I 19 & 0.334 & 0.202 & 0.234 & 0.223 & 0.005 & 0.349 & 0.412 & 0.413 \\
\hline I 15 & 0.118 & 0.327 & 0.317 & 0.345 & 0.348 & 0.005 & 0.388 & 0.400 \\
\hline I 14 & 0.121 & 0.336 & 0.326 & 0.355 & 0.358 & 0.007 & 0.391 & 0.407 \\
\hline I 12 & 0.121 & 0.336 & 0.326 & 0.355 & 0.358 & 0.007 & 0.391 & 0.407 \\
\hline I 10 & 0.118 & 0.326 & 0.317 & 0.345 & 0.348 & 0.002 & 0.381 & 0.397 \\
\hline I 4 & 0.413 & 0.336 & 0.390 & 0.377 & 0.402 & 0.382 & 0.005 & 0.091 \\
\hline A 2 & 0.004 & 0.322 & 0.311 & 0.315 & 0.328 & 0.116 & 0.417 & 0.431 \\
\hline A 1 & 0.330 & 0.007 & 0.137 & 0.101 & 0.199 & 0.332 & 0.345 & 0.359 \\
\hline A 8 & 0.324 & 0.004 & 0.137 & 0.101 & 0.197 & 0.327 & 0.339 & 0.354 \\
\hline A 9 & 0.313 & 0.139 & 0.005 & 0.113 & 0.238 & 0.317 & 0.396 & 0.402 \\
\hline A 3 & 0.310 & 0.133 & 0.004 & 0.111 & 0.236 & 0.314 & 0.390 & 0.399 \\
\hline A 15 & 0.316 & 0.137 & 0.004 & 0.111 & 0.236 & 0.320 & 0.396 & 0.402 \\
\hline A 4 & 0.316 & 0.105 & 0.111 & 0.011 & 0.229 & 0.349 & 0.385 & 0.386 \\
\hline A 14 & 0.312 & 0.101 & 0.107 & 0.005 & 0.221 & 0.343 & 0.371 & 0.368 \\
\hline A 13 & 0.321 & 0.107 & 0.113 & 0.009 & 0.228 & 0.348 & 0.378 & 0.374 \\
\hline A 5 & 0.312 & 0.099 & 0.105 & 0.002 & 0.223 & 0.343 & 0.374 & 0.370 \\
\hline A 12 & 0.325 & 0.197 & 0.233 & 0.223 & 0.002 & 0.343 & 0.405 & 0.406 \\
\hline A 6 & 0.325 & 0.197 & 0.233 & 0.223 & 0.002 & 0.343 & 0.405 & 0.406 \\
\hline A 11 & 0.342 & 0.202 & 0.234 & 0.224 & 0.013 & 0.349 & 0.409 & 0.404 \\
\hline A 7 & 0.342 & 0.202 & 0.234 & 0.224 & 0.013 & 0.349 & 0.409 & 0.404 \\
\hline A 10 & 0.431 & 0.357 & 0.397 & 0.377 & 0.410 & 0.397 & 0.091 & 0.005 \\
\hline B 1 & 0.002 & 0.324 & 0.313 & 0.318 & 0.331 & 0.118 & 0.416 & 0.433 \\
\hline B 2 & 0.330 & 0.005 & 0.139 & 0.103 & 0.200 & 0.327 & 0.337 & 0.352 \\
\hline B 4 & 0.330 & 0.005 & 0.130 & 0.099 & 0.202 & 0.333 & 0.343 & 0.357 \\
\hline B 3 & 0.315 & 0.103 & 0.109 & 0.005 & 0.221 & 0.346 & 0.372 & 0.371 \\
\hline B 5 & 0.318 & 0.105 & 0.111 & 0.007 & 0.226 & 0.349 & 0.378 & 0.374 \\
\hline B 8 & 0.318 & 0.103 & 0.105 & 0.005 & 0.223 & 0.348 & 0.380 & 0.376 \\
\hline B 7 & 0.325 & 0.197 & 0.233 & 0.223 & 0.002 & 0.343 & 0.405 & 0.406 \\
\hline B 6 & 0.336 & 0.202 & 0.233 & 0.223 & 0.013 & 0.343 & 0.406 & 0.400 \\
\hline
\end{tabular}


Tab. 2. Fungal operational taxonomic units (OTUs) identified in Orchis anthropophora (A), O. italica (I) and O. xbivonae $(\mathrm{X})($ marked by +$)$. Fungi were grouped into OTUs defined by $97 \%$ internal transcribed spacer (ITS) sequence similarity.

\begin{tabular}{llcccc}
\hline \multirow{2}{*}{ Target } & Family & Closest match & \multicolumn{3}{c}{ Presence in examined orchids } \\
\cline { 3 - 6 } & & in GenBank & A & I & B \\
\hline OTU-2 & Tulasnellaceae & GQ907254 & + & + & + \\
OTU-4 & Tulasnellaceae & GQ907260 & + & + & + \\
OTU-6 & Tulasnellaceae & GQ907266 & & + & \\
OTU-7 & Tulasnellaceae & GQ907258 & + & + & + \\
OTU-10 & Tulasnellaceae & GU066935 & + & + & + \\
OTU-11 & Ceratobasidiaceae & GU066936 & & + & \\
OTU-12 & Tulasnellaceae & HQ330992 & + & & + \\
OTU-17 & Ceratobasidiaceae & HQ331002 & + & & + \\
\hline
\end{tabular}
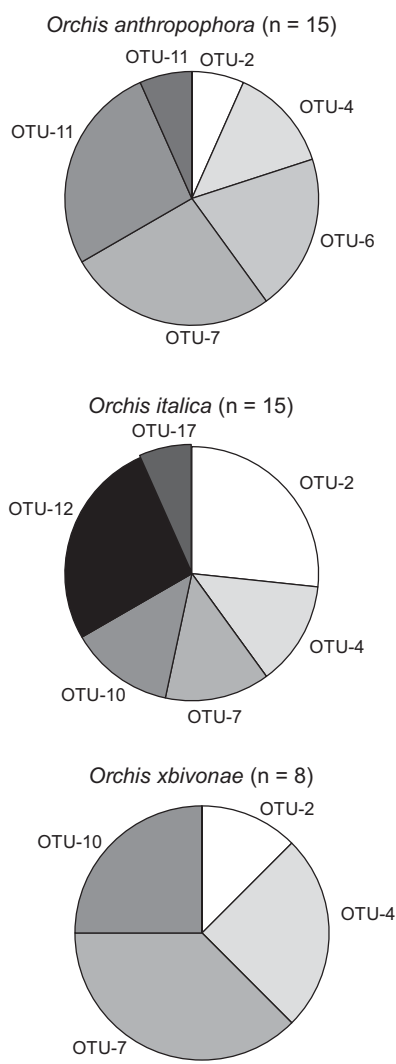

Fig. 1. Frequency distribution of identified operational taxonomic units (OTUs) in $O r$ chis anthropophora, $O$. italica and $O$. xbivonae.

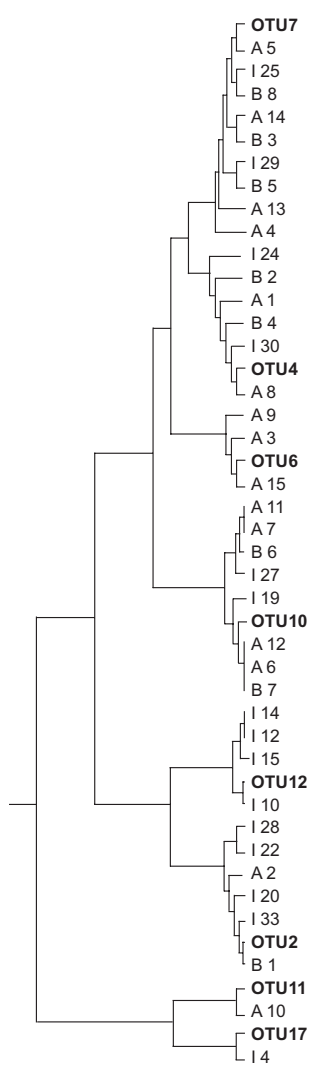

Fig. 2. Neighbour-joining phylogenetic tree showing the relationship between internal transcribed spacer (ITS) sequences for Orchis anthropophora (A), O. italica (I) and $O$. xbivona (B) mycobionts and operational taxonomic units (OTUs). 


\section{Discussion}

We have shown that adult plants of the two parental species and their hybrid associated with several frequently different fungal OTUs. First, 75\% of mycorrhizal fungi identified belong to Tulasnellaceae, a large, common group of orchid mycorrhizal fungi that have already been recorded in O. anthropophora and O. italica (JACQUEMYN et al. 2011b). Moreover, Tulasnellaceae have been recognized as the most important association with other Mediterranean orchids such as Anacamptis (GIRLANDA et al. 2011), Cypripedium (SHEFFERSON et al. 2007), Dactylorhiza (JACQUEMYN et al. 2012) and Ophrys (GIRLANDA et al. 2011). Previous literature showed that the number of fungal OTUs of Orchis sp. varied between one and nine; in detail $O$. anthropophora, O. italica, O. simia and $O$. militaris were associated with at least seven different OTUs, O.s purpurea with four, whereas O. anatolica, O. mascula, O. olbiensis and O. troodi with only one or two fungal OTUs (JACQUEMYN et al. 2010, JACQUEMYN et al. 2011a, b). In our case, in agreement with previous studies, $O$. italica and $O$. anthopophora were associated with six fungal OTUs, predominantly with OTU 2 and 12 (O. italica) and with OTU 7 and 10 (O. anthopophora) (Fig. 1). Orchis italica and $O$. anthopophora associated secondly with two different OTUs belonging to Ceratobasidiaceae confirming previous results (JACQUEMYN et al. 2011b).

Orchis xbivonae associated with fewer mycorrhizal fungi in comparison with its two parental species. Similar fungi occurred in the two parents, perhaps due to the close phylogenetic positions of the two parental species (BATEMAN et al. 2003). Similarly, micorrhizal fungi of Orchis xbergonii mostly belonged to Tulasnellales associated with the two parental species ( $O$. simia and $O$. anthopophora) and that the fungi associated with hybrids had less-diverse sequences than those associated with the parental species (SCHATZ et al. 2010).

Hybrid zones are notable for studying reproductive barriers among closely related species, role of selection in maintaining or eroding species differences, and role of hybridization in plant evolution (RIESEBERG and BUERKLE 2002, LEXER et al. 2005). Essential conditions for speciation by hybridization are that the hybrid exploits an ecological niche, either the parental one or a totally new one, shows an own reproductive success and produces a sufficient number of seeds (ARNOLD 1997). Compared to parental species, previous study demonstrated that $O$. xbivonae showed low fruiting values in open-pollinated flowers and the absence of any form of postmating isolation (PELLEGRINO et al. 2009). The low levels of reproductive success, the lack of post-zygotic barriers and of $\mathrm{F}_{2}$ (or later) generations (PELLEGRINo et al. 2009) suggest that the mycorrhizal symbiosis imposes no constraints on the survival of hybrids, and that the lack of pollinators appears to strongly limit hybrid fitness, as has previously been reported in parental species (PELLEGRINO et al. 2010) and other deceptive orchids (MAtTila and Kuitunen 2000, Pellegrino et al. 2005, SMITHSON 2006).

The coexistence of Orchis xbivonae with its parents suggests that this hybrid is a short-term by-product due to the behavior of shared pollinators (ScHATz 2006). Mycorrhizal do not represent a limitation to $O$. xbivonae growth but at the same time do not offer an ecological opportunity to partially separate hybrid habitat from the parental ones. In our case the low specificity and divergent association pattern between hybrids and parental species do not represent an effective barrier to hybridization. Indeed, hybrids and parental species share most of their mycorrhizal fungi, and thus no such incompatibilities are to be 
expected, and post-mating barriers at the seed germination stage should be weak, implying that mycorrhizal associations only play a minor role in affecting hybridization between orchids.

Overall, these results indicate that our hybrid zone represents a phenomenon of little evolutionary meaning and that the few hybrid plants will not easily origin descendents with potential new genetic combinations and/or ecological preferences. In conclusion, our results corroborate the idea that hybrid zone did not have a prominent role in speciation processes of Mediterranean orchids. Indeed, with the exclusion of one case (Orchis xcolemanii) in which the hybrids showed high levels of reproductive success and belonged to $F_{2}$ hybrid generation (LuCA et al. 2012), representing a potential reserve of adaptive variability (RIESEBERG 1995), natural hybridization do not show a high biological and evolutionary significance, but, rather, represent a strong postzygotic barriers actively maintain parental species boundaries from genome-wide introgression.

\section{References}

ARNOLD, M. L., 1997: Natural hybridization and evolution. Oxford University Press, New York, New York, USA.

Bateman, R. M., Hollingsworth, P. M., Preston, J., Yi-Bo, L., Pridgeon, A. M., Chase, M. W., 2003: Molecular phylogenetics and evolution of Orchidinae and selected Habenariinae (Orchidaceae). Botanical Journal of the Linnean Society 142, 1-40.

Bianco, P., Medagli, P., D’Emerico, S., Ruggiero, L., 1987: Numeri cromosomici per la flora Italiana. Informatore Botanico Italiano 19, 322-332.

Bidartondo, M. I., Burghardt, B., Gebauer, G., Bruns, T. D., Read, D. J., 2004: Changing partners in the dark: Isotopic and molecular evidence of mycorrhizal liaisons between forest orchids and trees. Proceeding of the Royal Society B: Biological Sciences 271, 1799-1806.

BidARTONDO, M. I., READ, D. J., 2008: Fungal specificity bottlenecks during orchid germination and development. Molecular Ecology 17, 3707-3716.

Bonnardeaux, Y., Brundrett, M., Batty, A., Dixon, K., Koch, J., Sivasithamparam, K., 2007: Diversity of mycorrhizal fungi of terrestrial orchids: Compatibility webs, brief encounters, lasting relationships and alien invasions. Mycological Research 111, 51-61.

Cameron, D. D., Leake, J. R., ReAD, D. J., 2006: Mutualistic mycorrhiza in orchids: Evidence from plant - fungus carbon and nitrogen transfers in the green-leaved terrestrial orchid Goodyera repens. New Phytologist 171, 405-416.

Caumet-Marc, A. M., Balayer, M., 1986: Les Orchidees du bassin Mediterraneen. Contribution a l'etude caryolgique des especes des Pyrenees-orientales (France) et contrees limitrophes. II - tribu des Ophrydae Lindl. pro parte. Bulletin de la Societe Botanique de France, Lettres Botanique 133, 265-277.

Costantinidis, T., KAMARI, G., PHitos, D., 1997: A cytological study of 28 phanerogams from the mountains of SE Sterea Ellas, Greece. Willdenowia 27, 121-142.

CribB, P. J., Kell, S. P., DiXON, K. W., BARrett, R. L., 2003: Orchid conservation: a global perspective. In: DiXon, K. W., Kell, S. P., Barrett, R. L., CribB, P. J. (eds.), Orchid conservation, 1-24. Natural History Publications, Kota Kinabalu Sabah. 
DeARlaney, J. W. D., 2007: Further advances in orchid mycorrhizal research. Mycorrhiza $17,475-486$.

Delforge, P., 2005: Orchids of Europe, North Africa and the Middle East. Timber Press, Portland, Oregon.

DNA DATA BANK OF JAPAN (2013): Home page. Retrieved January 10, 2014 from http://www. ddbj.nig.ac.jp

DrESSLER, R. L., 1993: Phylogeny and classification of the orchid family. Dioscorides Press, Portland, OR.

DoYLE, J. J., 1991: DNA protocols for plants - CTAB total DNA isolation, In: HewITT, G. M., Johnston, A. (eds.), Molecular techniques in taxonomy, 283-293. Springer Verlag, Berlin.

Girlanda, M., Segreto, R., Cafasso, D., Liebel, H. T., Rodda, M., Ercole, E., CozzoLino, S., Gebauer, G., Perotto, S., 2011: Photosynthetic Mediterranean meadow orchids feature partial mycoheterotrophy and specific mycorrhizal associations. American Journal of Botany 98, 1148-1163.

Hollick, P. S., TAYlor, R. J., McComb, J. A., Dixon, K. W., 2005: If orchid mycorrhizal fungi are so specific, how do natural hybrids cope? Selbyana 26, 159-170.

Irwin, M. J., Bougoure, J. J., Dearnaley, J. D. W., 2007: Pterostylis nutans (Orchidaceae) has a specific association with two Ceratobasidium root associated fungi across its range in Eastern Australia. Mycoscience 48, 231-239.

Jersáková, J., Johnson, S. D., Kindlmann, P., 2006: Mechanisms and evolution of deceptive pollination in orchids. Biological Reviews 81, 219-235.

Jacquemyn, H., Honnay, O., Cammue, B. P. A., Brys, R., Lievens B., 2010: Low specificity and nested subset structure characterize mycorrhizal associations in five closely related species of the genus Orchis. Molecular Ecology 19, 4086-4095.

Jacquemyn, H., Merckx, V., Brys, R., Tyteca, D., Cammue, B. P. A., Honnay, O., LIEVENS, B., 2011a: Analysis of network architecture reveals phylogenetic constraints on mycorrhizal specificity in the genus Orchis (Orchidaceae). New Phytologist 192, $518-518$.

Jacquemyn, H., Brys, R., Cammue, B. P. A., Honnay, O., Lievens B., 2011b: Mycorrhizal associations and reproductive isolation in three closely related Orchis species. Annals of Botany 107, 347-356.

Jacquemyn, H., Deja, A., De Hert, K., Cachapa Bailarote, B., Lievens, B., 2012: Variation in mycorrhizal associations with Tulasnelloid fungi among populations of five Dactylorhiza species. PLoS ONE 7, e42212.

Julou, T., Burghardt, B., Gebauer, G., Berveiller, D., Damesin, C., Selosse, M., 2005 : Mixotrophy in orchids: insights from a comparative study of green individuals and nonphotosynthetic individuals of Cephalanthera damasonium. New Phytologist 166, 639-653.

LEAKE, J. R., 1994: The biology of myco-heterotrophic ('saprophytic') plants. New Phytologist 127, 171-216.

Lexer, C., Fay, M. F., Joseph, J. A., NicA, M. S., Heinze, B., 2005: Barrier to gene flow between two ecologically divergent Populus species, $P$. alba (white poplar) and $P$. 
tremula (European aspen): the role of ecology and life history in gene introgression. Molecular Ecology 14, 1045-1057.

Luca, A., Bellusci, F., Menale, B., Musacchio, A., Pellegrino, G., 2012: Orchis xcolemanii hybridization: Molecular and morphological evidence, seed set success, and evolutionary importance. Flora 207, 753-761.

Mattila, E., Kuitunen, M. T., 2000: Nutrient versus pollination limitation in Platanthera bifolia and Dactylorhiza incarnata. Oikos 89, 360-366.

McCormick,M. K., Whigham, D. F., O’ NeIL, J., 2004: Mycorrhizal diversity in photosynthetic terrestrial orchids. New Phytologist 163, 425-438.

McCormick, M. K., Whigham, D. F., Sloan, D., O’ Malley, K., Hodkinson, B., 2006: Orchid - fungus fidelity: A marriage meant to last? Ecology 87, 903-911.

NATional CENTER FOR Biotechnology Information, 2013: Home page retrieved December 10, 2013 from http://www.ncbi.nlm.nih.gov/

Otero, J. T., Flanagan, N. S., Herre, E. A., Ackerman, J. D., Bayman, P., 2007: Widespread mycorrhizal specificity correlates to mycorrhizal function in the Neotropical, epiphytic orchid Ionopsis utricularioides (Orchidaceae). American Journal of Botany 94, 1944-1950.

Pellegrino, G., D’Emerico, S., Musacchio, A., Scrugli, A., Cozzolino, S., 2005: Confirmation of hybridization among sympatric insular populations of Orchis mascula and O. provincialis. Plant Systematics and Evolution 251, 131-142.

Pellegrino, G., Bellusci, F., Musacchio, A., 2009: Genetic integrity of sympatric hybridizing plant species. The case of $O$. italica and O. anthropophora. Plant Biology 11, 434-441.

Pellegrino, G., Bellusci, F., Musacchio A., 2010: The effects of inflorescence size and flower position on female reproductive success in three deceptive orchids. Botanical Studies 51, 351-356.

Phillip, R. D., Barrett, M. D., Dixon, K. W., Hopper, S. D., 2011: Do mycorrhizal symbioses cause rarity in orchids? Journal of Ecology 99, 858-869.

QueIRos, M., 1985: Números cromosómicos para a flora Portuguesa. Boletim da Sociedade Broteriana 58, 85-96.

Rasmussen, H. N., 1995: Terrestrial orchids: From seeds to mycotrophic plant. Cambridge University Press, Cambridge, UK

RASMUSSEN, H. N., 2002: Recent developments in the study of orchid mycorrhiza. Plant Soil 244, 149-163.

RENNER, S. S., 2005: Rewardless flowers in the angiosperms and the role of insect cognition in their evolution. In: WASER, N. M., OLLERTON, J. (eds.), Plant-pollinator interactions: From specialization to generalization, 123-144. University of Chicago Press, Chicago.

RIESEBERG, L. H., 1995: The role of hybridization in evolution: old wine in new skins. American Journal of Botany 82, 944-953.

RieseberG, L. H., Buerkle, C. A., 2002: Genetic mapping in hybrid zones. American Naturalist 159, 36-50. 
Roy, M., Whatthana, S., Richard, F., Vessabutr, S., Selosse, M., 2009: Two mycoheterotrophic orchids from Thailand tropical dipterocarpacean forests associate with a broad diversity of ectomycorrhizal fungi. BMC Biology 7, 51.

SAITOU, N., NeI, M., 1987: The neighbor-joining method: a new method for reconstructing phylogenetic trees. Molecular Biology and Evolution 4, 406-425.

SCHATZ, B., 2006: Fine scale distribution of pollinator explains the occurrence of the natural orchid hybrid x Orchis bergonii. Ecoscience 13, 111-118.

Schatz, B., Geoffroy, A., Dainat, B., Bessière, J., Buatois, B., Hossaert-McKey, M., Selosse, M., 2010: A case study of mofified interactions with symbionts in a hybrid Mediterranean orchid. American Journal of Botany 97, 1278-1288.

Scopece, G., Musacchio, A., Widmer, A., Cozzolino, S., 2007: Patterns of reproductive isolation in Mediterranean deceptive orchids. Evolution 61, 2623-2624.

SElosse, M. A., Roy, M., 2009: Green plants that feed on fungi: facts and questions about mixotrophy. Trends in Plant Sciences 14, 64-70.

Selosse, M. A., Scappaticci, G., Faccio, A., Bonfante, P., 2004: Chlorophyllous and achlorophyllous specimens of Epipactis microphylla (Neottieae, Orchidaceae) are associated with ectomycorrhizal septomycetes, including truffles. Microbial Ecology 47, $416-426$.

Shefferson, R. P., Weiß, M., Kull, T., TAYlor, D. L., 2005: High specificity generally characterizes mycorrhizal association in rare lady's slipper orchids, genus Cypripedium. Molecular Ecology 14, 613-626.

Shefferson, R. P., Taylor, D. L., Weib, M., Garnica, S., McCormick, M. K., Adams, S., Gray, H. M., McFarland, J. W., Kull, T., Tali, K., Yukawa, T., Kawahara, T., MiyoSHI, K., LEE, Y. I., 2007: The evolutionary history of mycorrhizal specificity among lady's slipper orchids. Evolution 61, 1380-1390.

Shefferson, R. P., Kull, T., TALI, K., 2008: Mycorrhizal interactions of orchids colonizing Estonian mine tailings hills. American Journal of Botany 95, 156-164.

Shimura, H., Sadamoto, M., Matsuura, M., Kawahara, T., Naito, S., Koda, Y., 2009: Characterization of mycorrhizal fungi isolated from the threatened Cypripedium macranthos in a northern island of Japan: two phylogenetically distinct fungi associated with the orchid. Mycorrhiza 19, 525-534.

SMith, S. E., 1966: Physiology and ecology of orchid mycorrhizal fungi with reference to seedling nutrition. New Phytologist 65, 488-499.

Smithson, A., 2006: Pollinator limitation and inbreeding depression in orchid species with and without nectar rewards. New Phytologist 169, 419-430.

STOCKINGER, H., KRÜGER, M., SCHÜßLER, A., 2010: DNA barcoding of arbuscular mycorrhizal fungi. New Phytologist 187, 461-474.

Tamura, K., Peterson, D., Peterson, N., Stecher, G., Nei, M., Kumar, S., 2011: MEGA5: Molecular evolutionary genetics analysis using maximum likelihood, evolutionary distance, and maximum parsimony methods. Retrieved January 17, 2014 from http://www. megasoftware.net. 
TAmura, K., NeI, M., 1993: Estimation of the number of nucleotide substitutions in the control region of mitochondrial DNA in humans and chimpanzees. Molecular Biology and Evolution 10, 512-526.

TAYlOR, D. L., McCormick, M. K., 2008: Internal transcribed spacer primers and sequences for improved characterization of basidiomycetous orchid mycorrhizas. New Phytologist 177, 1020-1033.

TAylor, D. L., Bruns, T. D., Hodges, S. A., 2004: Evidence for mycorrhizal races in a cheating orchid. Proceeding of the Royal Society B: Biological Sciences 271, 35-143.

Thompson, J. D., Higgins, D. G., GiBson, T. J., 1994: CLUSTAL W: improving the sensitivity of progressive multiple sequence alignment through sequence weighting, position-specific gap penalties and weight matrix choice. Nucleic Acid Research 22, 4673-4680.

Valadares, R. B., Pereira, M. C., Otero, J. T., Cardoso, E. J., 2012: Narrow Fungal Mycorrhizal Diversity in a Population of the Orchid Coppensia doniana. Biotropica 44, 114-122.

VAN DER PiJl, L., Dodson, C. H., 1966: Orchid flowers: their pollination and evolution. Coral Gables, Miami, USA: University of Miami Press.

Waterman, R. J., Bidartondo, M. I., Stofberg, J., Combs, J. K., Gebauer, G., Savolainen, V., Barraclough, T. G., Pauw, A., 2011: The Effects of above- and belowground Mutualisms on orchid speciation and coexistence. American Naturalist 177, 54-68.

White, T. J., Bruns, T. D., Lee, S. B., TAYlor, J. W., 1990: Amplification and direct sequencing of fungal ribosomal RNA genes for phylogenetics. In: Innis, M. A., Gelfard, H., Sninsky, J. S., White, T. J. (eds.), PCR-protocols and applications. A laboratory manual, 315-322. Academic Press, New York. 